\title{
ICT Integration in Secondary School Physics and Teachers' Attitude Towards Using ICT in Teaching Physics in Mombasa County, Kenya
}

\author{
Charles Mwambela $^{1^{*}} \quad$ Prof. Helen Mondoh ${ }^{1} \quad$ Prof. Thomas Thoruwa $^{2}$ \\ 1. School of Education, Pwani University, P.O.Box 195-80108 Kilifi, Kenya \\ 2. School of Pure and Applied Sciences, Pwani University, P.O.Box 195-80108 Kilifi, Kenya
}

\begin{abstract}
Information and Communication Technology (ICT) provides an opportunity for Educational Institutions and other organisations to harness and use technology to complement and support the teaching and learning process. However, despite the enormous advocacy for ICT-aided teaching and learning, investment and donation of ICT equipment to schools, there is a challenge on how to transform students learning process to provide students with the skills to function effectively in this information-rich and dynamic environment. Unless ICT is effectively integrated in teaching and learning, the investment for the development of ICT in schools will be wasted. The school curriculum may also fail to achieve its mission to produce learners who are ready for the world of work, which is increasingly reliant on ICT- aided generation and dissemination of knowledge. This study was aimed at finding out the extent of ICT integration in secondary school Physics and the teachers' attitude towards the using ICT in teaching Physics. Further. The study also assessed the extent to which the National ICT policy on education has been implemented in Mombasa County. It also assessed the teachers attitude towards teaching Physics using ICT. The study was done through administering questionnaires to 148 Physics teachers in public and private secondary schools, and conducting interviews with three (3) ICT champions in the county. The quantitative data based on a Likert Scale was analysed with the aid of the SPSS computer software (version 20) while the qualitative data was analysed using the Bryman's Four Stage Qualitative Analysis.
\end{abstract}

Keywords: Information and Communication Technology, Attitude.

DOI: $10.7176 / \mathrm{JEP} / 10-27-04$

Publication date:September $30^{\text {th }} 2019$

\section{Introduction}

The role of technology in teaching and learning is rapidly becoming one of the most important and widely discussed issues in contemporary Education Policies (Rosen \& Michelle, 1995; Thierer, 2000). Most experts in the field of Education agree that, when properly used, Information and Communication Technology (ICT) holds a great promise to improving teaching and learning and to shaping workforce opportunities. Poole, (1996) indicated that computer illiteracy is now regarded as the new illiteracy. Ofodu (2007) refers to Information and Communication Technology (ICT) as electronic or computerised devices, assisted by human and interactive materials that can be used for a wide range of teaching and learning as well as for personal use.

Improving school ICT facilities is essential in view of the current global revolution in teaching due to the changing nature of teachers' work, the realities of the information age, new global partnerships and awareness of technological changes (Feldner, 2003). Schools should therefore provide adequate ICT tools to enhance integration of ICT in teaching.

According to Kashorda, Waema, Omosa \& Kyalo, (2007), the introduction of ICT in education was part of the more fundamental objective to improve education globally and to make it accessible to everyone. They observed that the use of ICT in education had the potential to enhance the quality of teaching and learning, the research productivity of teachers and students, and the management and effectiveness of institutions.

ICT has the opportunity to revolutionise pedagogical methods, expand access to quality education and improve the management of education (World Bank, 2001). ICT is regarded as a critical tool for preparing and educating students with the required skills for the global work place (Ibe-Bassey, 2011).

According to Anthony (2012), the impact of ICT in education cannot be overemphasised. He noted that ICT solves problems concerning space and time. Accordingly, through ICT, the students can communicate, contact their teachers and collect and exchange information anywhere and anytime. Further, ICT also gives access to knowledge hence enabling the students to draw from a global pool of knowledge and also makes serving and sharing of knowledge easier. The students can therefore individually or together create records of notes and presentations which may help them to do better in their examinations. This way they are also trained for future participation in global research and communication.

\subsection{Statement of the Problem}

According to research, in many countries, all the investments in ICT infrastructure, equipment and professional 
development to improve teaching have produced little evidence on improvement of students' academic performance. In Kenya, the scenario has not been different. Further, it is not also clear whether the various aspects of the ICT Integration Policy have been implemented as per guidelines. It is therefore necessary to find the missing link between investment, policy and the students' academic achievement,

\subsection{Research Questions}

The research aimed at answering the following six questions:-

1. To what extent has the Kenyan National ICT Policy on Education been implemented in Mombasa County?

2. To what extent has ICT been applied in teaching of Physics in Mombasa County?

3. What is the attitude of the Physics teachers towards using ICT in the teaching of Physics?

\subsection{Literature Review}

\subsection{The National ICT Policy on Education}

In 2006, the government disseminated the National ICT policy on Education, with one of the objectives being to encourage the use of ICT in schools, colleges, universities and other educational institutions in the Country, so as to improve the quality of teaching and learning (Republic of Kenya, 2006). In this Policy, the section on secondary schools indicated that the government was to employ a number of strategies; and in particular, adoption and use of ICT in schools through promoting affordable ICT infrastructure in schools. This was aimed to facilitate acquisition of skills and knowledge through e-learning. Other strategies were; creating awareness of opportunities offered by ICT in schools, promoting development of local e-content in order to address the needs of individual schools, promoting enabling environment for integrating e-learning in curriculum to support ICT in schools and promoting integration of ICT resources with other existing school resources. Others were to encourage the use and adoption of ICT in schools, establishing a national ICT Centre of Excellence where schools could draw parallels, facilitating sharing of ICT resources between schools, promoting public-privatepartnerships in mobilising resources to support ICT initiatives in schools, promoting and facilitating training of teachers and school managers on ways to adopt and use ICT through in-service courses and facilitating rural electrification and connection of schools to the electricity grid in order to support ICT (GOK,2006).

Before the National ICT policy was developed, the Ministry of Education had already developed the Kenya Education Sector Support Programme (KESSP). KESSP was developed in order for the Government to achieve the vision for education and training in Kenya, which was to 'provide 'Elimu Bora kwa Maendeleo' or Quality Education and Training for Development (Government of Kenya, 2005).

\subsection{Extent of the use of ICT in Teaching in Secondary Schools}

A number of attempts have been made to improve the economy of Kenya, one of them being the Economic Blueprint (Vision 2030) anchored on knowledge based economy with ICT as the main driver in all sectors including education. To achieve the Vision 2030 in education, a number of initiatives have been started to introduce computer studies in schools and to integrate ICT in pedagogy. Some of the initiatives include: the teacher in-service training (INSET programmes) aimed at starting computer studies in schools and integrate ICT to teaching through training some teachers in secondary schools as trainers of trainers (ToTs). Participants in elearning teaching methods were selected from Teachers Training Colleges (TTCs), Centre for Mathematics Science and Technology in Africa (CEMASTEA), Kenya Institute of Curriculum Development (KICD) and Kenya Education Staff Institute (KESI). These participants were incorporated in readiness to teach others (Gitonga, 2009). Furthermore, Ayere, et al. (2010) were of the view that Kenyan schools participating in a project sponsored by (NEPAD) which introduced ICT integration would also act as model schools and other schools would replicate the successes achieved.

In 2010, the Ministry of Education, Science and Technology (MOEST) identified five schools in each of the former constituencies in Kenya and supplied them with ICT resources to jump start the ICT project in Kenya public schools. This was with the understanding that ICT was key in the improvement of education.

To make this project a success, Kenya Institute for Curriculum Development (KICD) prepared digitised content relevant to schools. This content was designed in such a way that it could be delivered using ordinary computer system, mobile phones and other mobile technology devices, therefore significantly transforming the way teaching and learning should be conducted. It was also web based for online access both locally and globally (Omuya 2012).

In order to encourage ICT integration in teaching and learning of Mathematics and sciences in secondary schools, Strengthening Mathematics and Science in Secondary Education (SMASSE) project adopted the use of ICT in classroom instruction. However, this could not be possible without schools having adequate ICT resources to facilitate the use of ICT in classroom instruction so as to promote learner centred methods of learning. (CEMASTEA, 2012)

According to CEMASTEA, although a number of Science Teachers have been in-serviced on the use of 
computers for instruction through SMASSE inset training, most of them still use the conventional instructional resources, which do not fully impart knowledge, skills and attitude to the learners resulting to poor performance in national exams. (CEMASTEA, 2014)

Regarding the extent of ICT integration in the teaching of Physics, a case study by Makanda (2015) on The Use of ICT in Teaching Physics revealed that ICT was mainly used at the planning stage of the lesson especially the typing of lesson plans and schemes of work. He noted that teachers also use computers to analyse students test scores. However, ICT use during lesson delivery was minimal despite the fact that most of the Physics teachers in the sampled schools had been trained in the use of computers. He noted that ICT will benefit both the teachers and the learners if it is used during lesson planning, lesson delivery and in assessment..

In a study that used a cross sectional descriptive survey, Kiptalam and Rodriguez (2010) looked at the utilization of the Internet among teachers and students in 11 connected rural and urban secondary schools in Kenya. The findings revealed that the use of the Internet and its integration in teaching and learning in secondary education was increasing among the students and teachers as a means of communication and for information searching. In addition, Internet access rates for teachers and students were observed to be much higher in educational institutions that had made effective ICT investments in education. Evidence from the study showed that teachers were integrating ICT in sciences, Mathematics, English, and Music. Teachers who used the Internet for communication was higher at $79.3 \%$ for urban-based teachers compared to $60 \%$ of rural-based teachers . Their study showed that about $44 \%$ of the teachers had over six years of using computers, while $11 \%$ had less than one year using computers. There also appeared to be a gender disparity with more male teachers having more experience in computer use than female teachers. The study suggested that ICT and its technologies are still at their infancy in Kenya, and that there is urgent need for incorporating ICT training for pre-service and professional development for in-service teachers.

\subsection{Teachers Attitude and the Use of ICT}

According to Ajzen and Fishbein (1977), attitudes refer to the ability to predict a person's behaviour toward certain targets. Ajzen (1988) described an attitude as a predisposition to respond favourably or unfavourably to an object, person, or event.

The strong relationship of computer-related attitudes and computer use in education has been emphasised in many studies (e.g., van Braak, 2001). Attitudes towards computers influence teachers' acceptance of the usefulness of technology, and also influence whether teachers will integrate ICT into their classroom (Akbaba \& Kurubacak, 1999); According to Myers and Halpin (2002), a major reason for studying teachers' attitudes is that it is a major predictor of future classroom computer use. Huang and Liaw (2005) also state that among the factors that affect the successful use of computers in the classroom, teachers' attitudes towards computers play a key role. Research by van Braak, Tondeur, and Valcke (2004) also supported that class use of computers was strongly affected by attitudes toward computers in education. Khine (2001) studied 184 pre-service teachers and found a significant relationship between computer attitudes and its use in the institution.

\subsection{Research Methodology}

The research design employed for this study was Descriptive Survey design. According to Walliman (2011), descriptive survey deals with describing a phenomena or the state of something. It included gathering data related to products, people, individuals, events and situations, and analyzing it (Traverse, 1978). The Descriptive Survey Study Design was employed in this study to define an opinion, attitude or behaviour held by Physics teachers on ICT integration in Physics Education. This was appropriate because the study involved collecting data in order to answer questions about the current status of ICT integration in the teaching of Physics in Secondary Schools in Mombasa County

\subsection{Research Instruments}

\subsubsection{Physics Teachers' Questionnaire, (PTQ)}

The first Section had four items that solicited for the background information about the teacher and the school in which he or she taught. The second section had 10 5-point Likert-type items arranged along the preferences SA (Strongly Agree), A (Agree), N (Neural) D (Disagree) and SA (Strongly Disagree). These items measured the teachers' attitude towards the use of ICT in teaching Physics. The third section had four (4) 5-point Likert-type items, along the continuum, SA (Strongly Agree), A (Agree), N (Neural) D (Disagree) and SA (Strongly Disagree), that rated the teachers' use of ICT in teaching Physics, The last section sought information on implementation of National ICT Policy on Education and had 10 5-point Likert-type items based on the proposed strategies on implementation of the National ICT Policy.

3.1.2 Interview Schedule for ICT Champions (ISIC)

This instrument was developed by the researcher based on the role of the ICT champions and the National ICT policy on Education. It had three sections. The first section had six items on personal information of the ICT 
champion while the last section was about National ICT Policy on Education and solicited for information for both quantitative and qualitative data, The researcher administered the instrument in form of discussions with the ICT champions.

\subsection{Results, Interpretations and Discussions}

\subsection{Implementation of the National ICT Policy on Education}

The first task in this study was to determine the extent to which the National ICT Policy on Education had been implemented in Mombasa County according to the first objective of this study. The data was extracted from item 21 to item 30 in the Physics Teachers Questionnaire (Appendix A), and the Interview Schedule for ICT Champions (Appendix E). The 10 items were statements on the objectives of National ICT Policy on Education, namely: Promoting affordable ICT infrastructure in schools in order to facilitate acquisition of skills and knowledge through e-learning,(item 21), Facilitating public-private partnership among the secondary schools to share resources in order to support e-learning initiatives. (item 22 ), Promoting development of local e-content (e.g. video clips and power point presentation) in order to address the ICT needs of individual schools (item 23), Promoting integration of ICT resources with other existing school resources (item 24) Establishing an ICT centre of excellence where your school can access(item 25 ). Others were: Facilitating sharing of ICT resources between schools (item 26); Promoting public - private partnership in mobilizing resources to support ICT initiatives in schools, (item 27); Promoting and facilitating training of teachers and school managers on ways to adopt and use ICT through in-service courses,(item 28 ); Facilitating rural electrification and connecting schools to electricity grid in order to support ICT, among other policies.(item 29) and Creating awareness through training on the use of ICT as an educational tool (item 30).

The teachers' responses ranged from Fully met (1) to Not met at all (5). The responses from the Physics Teachers are represented using the tables and bar charts. Table 10 shows the Physics Teachers' responses to the items on implementation of the National ICT Policy on Education Table 1: Teachers' Responses to National ICT Policy on Education

\begin{tabular}{llllllll}
\hline & Fully met & Met & Not sure & Not met & Not met at all & Mean & Sig. \\
\hline Item 21 & 6 & 62 & 16 & 28 & 16 & 2.89 & 0.000 \\
Item 22 & 4 & 20 & 46 & 38 & 26 & 3.45 & 0.001 \\
Item 23 & 6 & 48 & 26 & 38 & 16 & 2.52 & 0.000 \\
Item 24 & 10 & 18 & 44 & 22 & 22 & 3.24 & 0.000 \\
Item 25 & 2 & 32 & 36 & 34 & 30 & 3.24 & 0.007 \\
Item 26 & 8 & 24 & 52 & 30 & 20 & 3.43 & 0.001 \\
Item 27 & 8 & 56 & 34 & 18 & 18 & 3.22 & 0.455 \\
Item 28 & 42 & 54 & 20 & 8 & 10 & 2.87 & 0.000 \\
Item 29 & 22 & 52 & 39 & 16 & 8 & 2.16 & 0.000 \\
Item 30 & 4 & 28 & 48 & 40 & 14 & 3.07 & 0.055 \\
\hline Total & 112 & 404 & 356 & 270 & 180 & 3.0 & \\
\hline
\end{tabular}

Table 1 show the responses from the Physics teachers to the 10 items in the Physics teachers Questionnaire (PTQ) which were meant to address this objective. From these tables, out of the 1,324 responses to these items $515(39.0 \%)$ indicated that the stated objectives in these items were met or fully met while $452(34.1 \%)$ said the objectives were not met or not met at all. The average of the means was 3.0.

To find out whether the school category, i.e. whether private or public had any effect on the teachers opinion on whether the objectives stated in the 10 items have been met, a one way ANOVA was applied, with the school category as an independent variable and the teachers scores the dependent variables. It was observed that except for two items, the $\mathrm{p}$ values were less than 0.05 i.e. $\mathrm{p}<0.05$ (Table 1 )

\subsection{Extent of using ICT in the Teachingof Physics}

The second task in this study is to establish the extent to which ICT integration has been applied in teaching of Physics in Mombasa County, To obtain this data, 12 Likert scale items in section III of Physics Teachers' Questionnaire (PTQ) were used. These five point Likert scale items ranging from Strongly Agree(1) to Strongly Disagree(2) sought to find out whether Physics teachers use ICT to prepare their lessons, to prepare students exams and to analyse them. They also sought to find out whether the Physics teachers integrate ICT in teaching some selected topics perceived to be relatively abstract in nature. The results are shown in Table 2. 
Table 2 Teachers' responses to the use of ICT in Teaching Physics

\begin{tabular}{|c|c|c|c|c|c|c|c|c|c|}
\hline Statement & & spons & & & & & & & \\
\hline & SA & $\mathrm{A}$ & NS & $\mathrm{D}$ & $\mathrm{SD}$ & Missing & Mean & sd. & P;value. \\
\hline $\begin{array}{l}\text { I use ICT to prepare most of my Physics } \\
\text { lessons }\end{array}$ & 4 & 38 & 34 & 58 & 4 & 10 & 3.14 & 0.956 & 0.730 \\
\hline $\begin{array}{l}\text { I use ICT in teaching Rectilinear } \\
\text { propagation of Light }\end{array}$ & 56 & 18 & 10 & 48 & 4 & 12 & 2.46 & 1.403 & 0.105 \\
\hline I use ICT in teaching Electrostatics I & 16 & 46 & 20 & 52 & 4 & 10 & 2.87 & 1.132 & 0.384 \\
\hline I use ICT in teaching Electrostatics II & 15 & 47 & 22 & 54 & 0 & 10 & 2.83 & 1.080 & 0.654 \\
\hline $\begin{array}{l}\text { I use ICT in teaching Reflection at Curved } \\
\text { Surfaces }\end{array}$ & 13 & 47 & 26 & 48 & 2 & 12 & 2.84 & 1.070 & 0.107 \\
\hline I use ICT in teaching Waves I & 17 & 65 & 20 & 34 & 2 & 10 & 2.55 & 1.047 & 0.763 \\
\hline I use ICT in teaching Waves I & 25 & 65 & 12 & 32 & 2 & 12 & 2.41 & 1.092 & 0.322 \\
\hline I use ICT in teaching X-rays & 36 & 54 & 12 & 32 & 4 & 10 & 2.38 & 1.185 & 0.772 \\
\hline I use ICT in teaching Photoelectric Effect & 18 & 58 & 14 & 48 & 0 & 10 & 2.67 & 1.090 & 0.240 \\
\hline I use ICT in teaching Electronics & 26 & 58 & 14 & 38 & 2 & 10 & 2.51 & 1.129 & 0.451 \\
\hline I use ICT in analysing students' results & 67 & 45 & 4 & 20 & 2 & 10 & 1.87 & 1.106 & 0.159 \\
\hline I use ICT in preparing students exams & 75 & 55 & 0 & 12 & 2 & 4 & 1.68 & 0.944 & \\
\hline Total & 368 & 596 & 188 & 476 & 28 & & 30.21 & & \\
\hline
\end{tabular}

Note: SA-Strongly Agree, A-Agree, NS-Not Sure, D-Disagree, SD- Strongly Disagree

The results on the extent of using ICT in teaching Physics are recorded in Table 2. From the table, out of the 1,656 responses to the 12 items, 964 responses $(58.2 \%)$ ) either agreed or strongly agreed that Physics teachers use ICT in teaching Physics while in 506 responses $(30.4 \%)$ the teachers disagreed or strongly disagreed that they use ICT in teaching Physics. In 188 responses (11.4\%), teachers were neutral. Further, Table 2 shows that the average of the means for the 12 responses was 2.52.which is less than 3 (neutral).

From the summary of the results, the percentage of $58.2 \%$ for those teachers who agreed or strongly agreed that they use ICT in the teaching of Physics compared to the $30.4 \%$ who disagreed or strongly disagreed shows that generally teachers integrate ICT in teaching Physics. This suggests that more teachers integrate ICT in their Physics classes compared to those who do not. This disagrees with a study carried out by CEMASTEA, which concluded that although a number of Science Teachers have been in-serviced on the use of computers for instruction through SMASSE inset training, most of them still use the conventional instructional resources, which do not fully impart knowledge, skills and attitude to the learners resulting to poor performance in national exams (CEMASTEA, 2014). .It also disagrees with Makanda (2015), who observed that in The Use of ICT in Teaching Physics, ICT was mainly used at the planning stage of the lesson especially the typing of lesson plans and schemes of work. He noted that teachers also use computers to analyse students test scores. However, according to him, ICT use during lesson delivery was minimal despite the fact that most of the Physics teachers in the sampled schools had been trained on the use of computers (Makanda,2015).

To find out whether the school category, i.e. whether private or public, had any effect on the teachers' use of ICT in teaching Physics, a one way ANOVA statistical treatment was applied with the school category as the independent variable and the 12 items on the teacher' use of ICT in teaching being dependent variables. The pvalue for each item is shown in the last column in Table 2 . The p-value for the level of significance for each item was greater than 0.04 (i.e. $p>0.05$ ). This shows that the school category had no effect on the teachers' use of ICT tools in the teaching of Physics

\subsection{Teachers' Attitude towards using ICT in Teaching Physics}

The other task in this study was to determine the attitude of Physics teachers towards the use ICT in teaching Physics, To obtain this data, ten five-point Likert scale items in the Physics Teachers' Questionnaire were used. The responses ranged from strongly agree to strongly disagree. The teachers' responses to the ten items were as shown Table 3 .. 
Table 3.Teachers Attitude towards the use of ICT in Teaching Physics

\begin{tabular}{|c|c|c|c|c|c|c|c|c|c|}
\hline Statement & & Res & nse & & & & & & \\
\hline & SA & $\mathrm{A}$ & NS & $\mathrm{D}$ & SD & Missing & mean & sd & $\begin{array}{l}\mathrm{p}- \\
\text { value }\end{array}$ \\
\hline $\begin{array}{l}\text { School funds spent on ICT infrastructure are } \\
\text { well used }\end{array}$ & 6 & 77 & 47 & 8 & 4 & 6 & 2.49 & 0.788 & 0.086 \\
\hline I like spending time preparing ICT lessons & 14 & 96 & 18 & 16 & 0 & 4 & 2.25 & 0.780 & 0.355 \\
\hline Teaching in ICT lessons is fun & 71 & 69 & 4 & 2 & 0 & 2 & 1.58 & 0.620 & 0.798 \\
\hline Teaching using ICT motivates students & 92 & 52 & 2 & 0 & 0 & 2 & 1.38 & 0.515 & 0.106 \\
\hline $\begin{array}{l}\text { I prefer teaching most concepts in Physics } \\
\text { using ICT to using any other method }\end{array}$ & 26 & 73 & 16 & 20 & 2 & 12 & 2.26 & 0.983 & 0.000 \\
\hline $\begin{array}{l}\text { ICT facilitates teacher's research in a given } \\
\text { topic }\end{array}$ & 72 & 58 & 4 & 4 & 0 & 10 & 1.57 & 0.694 & 0.079 \\
\hline $\begin{array}{l}\text { ICT lessons improves teacher-student } \\
\text { communication }\end{array}$ & 45 & 75 & 10 & 8 & 0 & 10 & 1.86 & 0.788 & 0.608 \\
\hline ICT integration in teaching saves & .48 & 64 & 16 & 10 & 0 & 10 & 1.91 & 0.867 & 0.035 \\
\hline $\begin{array}{l}\text { ICT integrated lessons helps students to be } \\
\text { attentive }\end{array}$ & 52 & 76 & 4 & 6 & 0 & 10 & 1.74 & 0.718 & 0.658 \\
\hline I feel competent in using ICT tools in & 32 & 72 & 18 & 14 & 0 & 10 & 2.10 & 0,874 & 0.784 \\
\hline
\end{tabular}
teaching

\begin{tabular}{lrrrrrrr}
\hline Total & 458 & 712 & 139 & 88 & 6 & 76 & 19.14
\end{tabular}

Note: SA-Strongly Agree, A-Agree, NS-Not Sure, D-Disagree, SA- Strongly Disagree

From Table 3, out of the 1,479 responses to the 10 items, 1,170 responses $(79.1 \%)$ either agreed or strongly agreed to the items showing a positive attitude, while in 94 responses $(6.4 \%)$ the teacher disagreed or strongly disagreed showing a negative attitude. In 139 responses (9.4\%),teachers were neutral. Further, the table shows that the average of the means, for the 10 responses, was 1.91.which was less than 3 (neutral). This shows that the teachers had a strongly positive attitude toward the use of ICT in teaching Physics. We can therefore conclude that when teachers have a positive attitude towards the use of ICT, they can easily embrace it as a teaching method. This agrees with Buabeg-Andoh (2012) who observed that a positive attitude towards computer use by teachers is important to ensure the integration of ICT is effectively carried out in the school curriculum and also during teaching and learning. (Buabeg-Andoh,2012).

It also agrees with Olandosu (2012), in his study on Basic Technology, Teachers' Awareness and Attitude towards the use of ICT for Sustainable Development in Lagos Nigeria,who asserted that teachers attitude plays an important role in the teaching and learning process that involve computer and internet connections.

To find out whether the school category, i.e. whether private or public had any effect on the teachers attitude towards the use of ICT in teaching Physics, a one way ANOVA was applied with the school category as the independent variable and the 10 items on the use of ICT being dependent variables. The p-value of the level of significance for each item is shown in the last column in Table 38. The table shows that except for two items the $\mathrm{p}$ values are greater than 0.05 (i.e.p $>0.05$ ). This shows that on average, the school category had no significant effect on the teachers' attitude towards the use of ICT in teaching Physics.

\section{Summary, Conclusions and Recommendations}

\subsection{Summary}

Concerning implementation of the National ICT Policy on Education in Mombasa County, the study revealed that the average score of the Likert scale items on the National ICT Policy was 3.0, which represents a neutral opinion by the Physics teachers. This means that on average, the Physics teachers were neutral on whether the National ICT Policy on Education has been Implemented in Mombasa County or not.

When a one way ANOVA was applied, with the school category as an independent variable and the teachers score on the Likert scale items as the dependent variables, it was generally observed that the school category, i.e. whether public or private, had a significant effect on teachers' opinion on the extent to which the objectives of National ICT policy on Education were met. Teachers from public Secondary Schools were more positive compared to their counterparts in private Secondary Schools.

Regarding teachers' use of ICT during their Physics lessons, the summery of the results show that generally, more Physics teachers use ICT in their Physics classes compared to those who do not.

When a one way ANOVA was applied, with the school category (i.e. whether public or private school) as the independent variable and the 12 items on the use of ICT being dependent variables, the results show that the school category had no effect on the teachers' use of ICT tools in the teaching of Physics.

Concerning Physics teachers' attitude towards the use of ICT in teaching Physics, the average of the means for the 10 responses on the teachers attitude, was less than 3 (neutral). This shows that the teachers had a 
strongly positive attitude toward the use of ICT in teaching Physics.

To find out whether the school category (i.e. whether public or private), had any effect on the teachers attitude towards the use of ICT in teaching Physics, a one way ANOVA was applied with the school category as the independent variable and the 10 items on the use of ICT being dependent variables. The results show that on average, the school category had no significant effect on the teachers' attitude towards the use of ICT in teaching Physics.

\subsection{Conclusion}

To determine the extent of Implementation of the National ICT Policy on Education in Mombasa County, 10 items in the Physics Teachers' Questionnaire were used to obtain the required data. These items represented the various strategies proposed by the government under this policy. The average score for the 10 items on Likert scale was 3.0, which indicated that the teachers were generally neutral on whether the strategies were realised or not. This meant that the impact of the National ICT Policy was not felt in secondary schools as expected. The study also revealed that impact was felt more in Public schools compared to Private Schools. There is therefore need for the government to take some measures to ensure that the impact of this policy is felt more in both Public and Private Secondary Schools.

On teachers' use of ICT in teaching Physics lessons, the study revealed that more Physics teachers use ICT in teaching compared to those who do not, showing that the government efforts to in-service teachers on the use of ICT in the teaching process are being rewarded.

It is therefore evident that over the years, teachers are beginning to embrace ICT integration in the teaching of Physics. However, it is worth noting that the average of teachers' responses on the use of ICT in teaching, which was 2.52 shows that the extent of integration was not high since this value is not far from 3.0 which implies neutral. Follow-up programmes after the teachers, training sessions may be necessary to ensure more effective integration of ICT in the teaching of Physics.

The study also shows that that the school category, i.e. whether public or private, had no effect on the teachers' use of ICT tools in the teaching of Physics in Mombasa County despite the common notion that private secondary schools are more equipped with ICT resources and integrate ICT more in their teaching compared to public secondary schools.

\subsection{Recommendations}

The following recommendations were deemed appropriate for effective of ICT integration and effective use of ICT in the teaching of Physics.

i)Availing more ICT resources in schools required in the teaching of Physics. This can be done through funding or subsidising by the government. Schools should also allocate more funds for purchasing these resources. Teachers can also be encouraged to obtain their personal laptops and smart phones. This will help to sharpen their own skills in the use of ICT tools and to prepare their own e-content for use in their Physics lessons.

ii)Teachers should be trained on ICT skills from the college level regardless of the subjects they specialise in. The training being done in insets like SMASSE and thorugh the ICT champions at school level should be intensified and followed up to ensure that the skills imparted are transferred to classroom situation.

iii)The ICT rooms should be designed to accommodate full classes without congestion. Power sockets and white walls as screens should also be availed in classrooms for ICT integrated lessons. This minimises competition for ICT rooms and computer labs.

iv)Schools should employ an ICT technician for proper maintenance and repairs of the ICT equipment. The technician will also help to induct the new teachers on the use of ICT tools.

v)The Ministry of Education should supply adequate and relevant e-content for all topics for use in ICT integrated lessons since the schools may not be able to develop appropriate ones.

vi)There should be better maintenance of mains electricity power grid to minimise the frequent power failures experienced in our schools. Power generators should also be installed as a contingency measure in case of such power failures.

vii)The government should ensure the availability of stronger internet connections in schools to allow for easy access to online material.

viii)Private schools should not be left out when it comes to implementation of National ICT in education. This may be done by subsidising the ICT equipment for the schools, allowing them access to ICT centres, involving them in the training on the use of ICT among other measures.

\section{References}

Ajzen, I. (1991). The theory of planned behavior. Organizational Behavior and Human Decision Processes, 50, 179-211 
Ajzen, I., \& Fishbein, M. (1977). Attitude-behavior relations: A theoretical analysis and review of empirical research.Psychological Bulletin, 84, 888-918PDF

Akbaba, S., \& Kurubacak, G. (1999). Teachers' attitudes towards technology. Computers in the Social Studies, $7(2), 833-836$.

Anthony, O (2012). Challenges of effective use of ICT as a tool for implementing the UBE schemes 53rd annual conference of science teachers association of Nigeria 2012. HEBN publisher

CEMASTEA (2012).Monitoring and Evaluation report. Unpublished, Nairobi.

CEMASTEA (2014) ICT integration Manual for Teachers Unpublished.Nairobi, Kenya.

Feldner, L. M. (2003). The Role of School Administrators in Supporting Teachers in the Integration of Education Technology into K-12 Classrooms. PhD thesis. North Dakota: University of North Dakota. Accessed Oct 28, 2006 from http://0- proquest.umi.com.oasis.unisa.ac.za:80/pqdweb?did

Government of Kenya (2005) Session Paper No.1 of 2005 on a policy Framework for Education, Training and Research; Government printer, Nairobi Kenya

Government of Kenya (2006) National ICT strategy for Education and Training, Government printer. Nairobi Kenya

Huang, H. M., \& Liaw, S. S. (2005). Exploring users' attitudes andintentions toward the Web as a survey tool. Computers in Human Behavior, 21(5), 729-743

Ibe-Bassey, G.S (2011). Human capacity building for information and communication technology ICT integration in teacher education in Nigeria Association of educational media and technology (NAEMT

Kashorda, M, Waema, T, Omosa, M \& Kyalo, V (2007) E-readiness Survey of Higher Education Institutions [accessed 10 Nov 2013] http://ereadiness.kenet.or.ke/sites/default/files/Ereadiness_survey_of_Kenyan_HigherEducation_June2007

Khine M.S. (2001) Attitudes toward computers among teacher éducation students in Brunei Darussalam. International Journal of Instructional Media 28, 147-153.

Kiptalam, G. K., \& Rodrigues, A. J. (2010). Internet utilization: A case of connected rural and secondary schools in Kenya. International Journal of Computing and ICT Research, 4(1), 49 - 63.

Makanda J. L (2015). Use of ICT in Teaching Physics: A case of Secondary Schools inKimilili District, Bungoma County, Kenya.Unpublished.

Myers, J. M., \& Halpin, R. (2002). Teachers' attitudes and use ofmultimedia technology in the classroom: Constructivist-based professional development training for schooldistricts. Journal of Computing in Teacher Education, 18(4), 133-140.

Ofodu GO (2007). Nigeria Literary educators and their technological needs in a digital age. Educ. Focus 1(1): 22 -30 .

Omuya A (2012) Secondary School Curriculum to be Digitised Daily Nation.

Rosen, L., \& Michelle, W. (1995).Computer availability, computer experience and technophobia among public school teachers. Computer in Human Behaviour, 11, 9-31.

Thierer, A. (2000). Divided over the digital divide, Washington, DC: Heritage Foundation.

Traverse, R. (1978) Introduction to Educational Research (4 ${ }^{\text {th }}$ Edition) McMillan, London

van Braak, J. (2001), 'Individual characteristics influencing teachers' class use of computers', Journal of Educational Computing Research, 25(2), pp.141-157.

van Braak, J., Tondeur, J., \& Valcke, M. (2004). Explaining different types of computer use among primary school teachers. European Journal of Psychology of Education, 19, 407-422

Walliman, N. (2011) Research Methods: The basics. Routledge, London and NewYork 